\title{
Inhalt, Vol. 2, No. 4, 1979
}

\section{Contents}

Impressum Ill

Vutuc, Ch.; Herb erg, D.; Gredler, B. und

Kunze, M., Wien

Soziale Schicht und Bronchuskarzinom: Schichtstruktur

im Vergleich zur Gesamtbevölkerung

137

Buchbesprechungen 140

Kucera, H. und Michalica, W., Wien

Zur Epidemiologie des Gebärmutterhalskrebses in

Österreich 142

Ortner, A.; Klammer, J.; Mikuz, G. und Dapunt, O.,

Innsbruck

Papillomatöse Veränderungen der Cervix uteri

Lütgemeier, I.; Rössler, J.; Lütgemeier, J. und Hörst, M., Mannheim

Verschleppungszeit beim Mammakarzinom und Persön-

lichkeitsstruktur 152

Nöthiger, F., Aarau

Kolorektales Karzinom

156

Rücker, J. und Engels, M., Salzburg

Zur Problematik des Neuroblastoma sympathicum - Er-

fahrungen mit 10 eigenen Neuroblastompatienten .... 162

Mühe, E.; Gall, F. P.; Hermanek, P. und

Angermann, B., Erlangen-Nürnberg

Hat die Berechnung der Geschwindigkeit des Ge-

schwulstwachstums klinische Bedeutung? 166

Lubec, G. und Möschl, P., Wien

Enzyminduktion durch produzierende Infektion von lymphoblastoiden Zellinien durch Epstein-Barr-Virus . . 174

Rose, H.; Busse, E. und Riessbeck, K.-H., Berlin

Konzentrationsveränderungen zyklischer Nukleotide in verschiedenen Tumoren und Therapieerfolge durch Er-

höhung des cAMP-Spiegels 176

Imprint Ill

Vutuc, Ch.; Herberg, D.; Gredler, B., and

Kunze, M., Vienna

Social Class and Lung Cancer: Class Distribution

Compared with the General Population 137

Book Reviews 140 
Kucera, H. and Michalica, W., Vienna

On the Epidemiology of Cancer of the Cervix Uteri in

Austria142

Ortner, A.; Klammer, J.; Mikuz, G., and Dapunt, O., Innsbruck

Papillomatous Lesions of the Cervix Uteri 148

Lütgemeier, I.; Rössler, J.; Lütgemeier, J., and Hörst, M., Mannheim

Correlation Between Delaying Treatment of Breast

Cancer and Personality Structure 152

Nöthiger, F., Aarau

Colorectal Cancer 156

Rücker, J. and Engels, M., Salzburg

On the Problems of Neuroblastoma Sympathicum -

Experience with 10 Own Patients 162

Mühe, E.; Gall, F. P.; Hermanek, P., and

Angermann, B., Erlangen-Nürnberg

Is the Determination of the Rate of Tumor Growth of

Any Clinical Significance? 166

Lubec, G. and Möschl, P., Vienna

Evidence for Enzyme Induction in Productive Infection

with Epstein-Barr Virus

174

Rose, H.; Busse, E., and Riessbeck, K.-H., Berlin

Changes in the Concentration of Cyclic AMP in Different

Tumors and Therapeutic Results for Increase of the

cAMP Level 176

Bibliographischer Hinweis: Inhaltsverzeichnisse dieser Zeitschrift erscheinen regelmäßig in current contents ${ }^{\circledR}$ sowie in anderen bibliographischen Diensten. 